\title{
FNDC5 Gene
}

National Cancer Institute

\section{Source}

National Cancer Institute. FNDC5 Gene. NCI Thesaurus. Code C158409.

This gene may be involved in exercise-dependent metabolic processes. 